\title{
Correction to: A performative and genealogical approach to the liminal subject's social sustenance: the case of the disappeared detainees in Chile
}

\author{
Oriana Bernasconi ${ }^{1} \cdot$ Marcela Ruiz $^{2}$
}

Published online: 5 September 2018

(C) Springer Nature Limited 2018

\section{Correction to: Subjectivity https://doi.org/10.1057/s41286-018-0050-5}

The reference sources for the following figures did not acknowledge their documentary collection of origin. The complete reference sources are:

Fig. 4 'Where are they? Muriel Dockendorff Navarrete' Association of Relatives of the Disappeared Detainees. Museum of Memory and Human Rights, Fondo Mosciatti Ezzio

Fig. 5 'Where are they?' daughter of disappeared detained. April 18, 1979. In '20 años de historia de la Agrupación de Familiares de Detenidos Desaparecidos de Chile: un camino de imágenes" Santiago: Corporación Agrupación de Familiares de Detenidos Desaparecidos, 1997

Due to an error in figure 6 reference source, we show the correct reference source here:

The original article can be found online at https://doi.org/10.1057/s41286-018-0050-5.

Oriana Bernasconi

obernasc@uahurtado.cl

1 Sociology Department, Universidad Alberto Hurtado, Almirante Barroso 10, Santiago, Chile

2 Department of Language and Literature, Universidad Alberto Hurtado, Almirante Barroso 10, Santiago, Chile 
Fig. 6 'Where are they?' posters from 1984, 1990, 2006, the Association of Relatives of the Disappeared Detainees. Museum of Memory and Human Rights, Fondo CINPRODH; Fondo Navarrete Faraldo Magdalena

The principal author's affiliation is not Language and Literature Department but Sociology Department at Alberto Hurtado University.

The authors apologise for these errors. 